\title{
On the driving out of devils by Beelzebub in therapeutics
}

\author{
By Erwin H. Ackerknecht
}

When I started studying medicine in 1924, therapeutics were just between two "waves": the "antipyretic" and the "pyretic" ${ }^{1}$ one. The antipyretic wave was the result of the spreading of systematic measurements of temperatures as a control or the fighting of "fevers" by cold water since Currie (1797) - by the way actually preferable to the then orthodox calomel or tartarus stibiatus. The bible of temperature measurements was Wunderlich's "Eigenwärme in Krankheiten" (1868).

The antipyretic practice became a wave when through chemists and chemical industry numerous synthetic "antipyretics" became available (salicylic acid, Kolbe 1874; antipyrine, Knorr 1884; phenacetin, Hinsberg and Kast 1887, etc. etc.). They were cheaper and easier applicable than bathing or older drugs. Liebermeister provided in 1875 the theoretical underpinning for antipyresis in proving the higher loss of body substance during fevers ${ }^{2}$. Antipyresis became now a panacea. Towards the end of the century, in spite of the causal discoveries of bacteriology and the growing realisation of the toxicity of many antipyretics ${ }^{3}$, moderate antipyresis was still prevalent ${ }^{4}$.

In the 1920-ies so called "protein therapy" began to spread, that is fever producing proteins e.g. milk were injected in a number of diseases ${ }^{5}$. This fever therapy became a "pyretic wave" when J. Wagner von Jauregg, who had shown the curative effect of fever in psychoses in $1887^{6}$ and introduced the malaria treatment of general paresis in 1917, obtained the Nobelprice for this accomplishment in 1927. The old "morbi salutares" ideas had a modern renaissance. We injected now milk in arthritis, gonorrhea, asthma, cutaneous and ocular diseases. Some even in tuberculosis. I feel that this change from the antipyretic to the pyretic wave is an apt illustration in therapeutics of what is called in the New Testament: the driving out of devils by Beelzebub (Matth. 12,24).

That this event is by no means rare in the history of therapeutics, might be shown shortly by a few more examples. The unfortunate sufferers of rabies, a disease incurable up to Pasteur $(1885)^{7}$, were submitted to in- 
numerable and ever changing therapeutic procedures and remedies since antiquity. As a matter of fact the attempt of the "ancients" to destroy the poison at the place of introduction was preferable to the method of the "moderns" to attack it by internal medicaments ${ }^{8}$. Very characteristic in the course of this martyrology is what happened in 1823. At this time the most widespread treatments were mercury and seabathing (mentioned already by Mondeville ${ }^{9}$ ). Now Magendie, the great physiologist and father of modern pharmacology, found a new remedy, the intravenous injection of warm water! ${ }^{10}$ No need to insist that this was another appearance of Beelzebub.

The sovereign remedy against syphilis was up to Paul Ehrlich mercury ${ }^{11}$. Mercury had entered Western medicine through the Arabs. It had become a dominant remedy through Paracelsus (1493-1541), the alchemist and great "reformer" of medicine. His "spagyric" (chemical) school had replaced bleeding as a syphilis remedy by mercury. The mercury treatment was rather a torture. It was opposed by many (e.g. Fernel) and around 1520 replaced by the American "holy wood" guaiac ${ }^{12}$. But guaiac treatment being a veritable Beelzebub, and in addition inefficient, disappeared as syphilis remedy after a few decades and mercury came back around 1560. Mercury, especially as calomel, by the way remained such a panacea that around the middle of the 19th century all bones in anatomies contained $\mathrm{Hg}$, and Fanconi demonstrated as late as 1947 that "acrodynia" which still appeared in epidemics, and had been still classified by Fanconi's predecessor Feer as "neurosis" (1923), was simply mercury poisoning, caused by calomel abuse.

The favorite (very toxic) metal of the Paracelsians was antimony the "regulus". Is was especially popular as the tartarus stibiatus or emeticus of Mynsicht. It became extremely fashionable in the 17th century after it had "cured" a fever of Louis XIV ${ }^{13}$. The very influential Scotch reformer John Brown (1735-88) - with his omnipresent "asthenia" an afterbirth of ancient methodism - replaced now antimony and venesection by alcohol and opium with catastrophic results ${ }^{14}$. Another Beelzebub was the reformer Broussais who condemned antimony and other medicaments, but killed his patients with leeches and a starvation $\operatorname{diet}^{15}$.

The famous Vienna clinician Stoll (1742-1787) was a great admirer of Tartarus emeticus. But realising its inefficiency, he switched to "vampyrism" (venesection). As he applied this to himself too, and as he was tuberculous, he died at age 45 .

Cancer therapy oscillated always between surgery, and salves and medicaments, both methods being highly unsuccessful. Arsenic salves were 
already mentioned by Celsus and became very popular with the Arabs and in the Renaissance without solving the problem.

Negative results with As-treatment as cancer treatment or substitute for quinine produced a true Arsenicophobia around 1780. When in 1901 a new As-drug was introduced in treatment, it received the name of "Atoxyl" (the non toxic!). Those blinded by it, might have later called it Beelzebub ${ }^{16}$. The thyreotoxicosis produced by the introduction of Iodine into goiter treatment around 1830, is well known. The therapeutic nihilism of Dietl and Co. in Vienna around 1825 is in a way a case of Beelzebubism too. The same label deserves also the "Neuralpathology" (liquor pumping) of the prominent stalinist doctor Speransky (1950) ${ }^{17}$.

Drug addiction became quite a problem since Sertürner had isolated in 1806 Morphine in Opium (and died as an addict) and A. Wood had invented the hypodermic syringe in 1855. In the "substitution treatment" of morphinism by other narcotic drugs, the same grave mistake has been repeated at least five times. In 1878 Bentley substituted cocaine. A few years later Hammond, L. Lewin, Erlenmeyer and others showed that the addict either exchanged only one addiction for the other, or had now two. The same situation repeated itself when heroin was prescribed for substitution of morphine in 1898. This did not prevent the use of demerol (1940) for the same purpose. In discussing the present use of methadon as a substitute for heroin, Kryspine-Exner speaks - it seems to me rightly — of "driving out the devil with Beelzebub" 18. The use of ether to replace alcohol in addicts deserves the same characterisation.

The causes for this phenomenon are, of course, manifold and complex. Doctors are almost always under pressure to find new and better remedies. Many seem to develop a true inclination toward new remedies (neophilia) ${ }^{19}$. It has also been well known for quite some time, that fashion has not only a strong influence in garments or travels, art, science, food, religion, jurisdiction, philosophy, technology, but also in medicine, especially therapeutics ${ }^{20}$. And that fashions have sometimes a tendency to change abruptly, according to the old pendulum rythm.

\section{Footnotes}

1 see Ackerknecht, E. H. Aspects of the history of therapeutics. Bull. Hist. Med. 36: 407, 1962. 
Rageth, S. Die antipyretische Welle in der 2. Hälfte des 19. Jahrhunderts. Diss. Zürich 1964.

Ackerknecht, E. H. Therapie von den Primitiven zum 20. Jahrhundert. Stuttgart 1970, p. 126.

2 Koelbing, H. M. Carl Liebermeister (1833-1901), Gesnerus 26: 233-48, 1969.

3 Lasagna, L. Diseases drugs cause. Perspectives in Biology and Medicine, 1964, 7: 458.

4 Rageth, l.c. p. 38.

5 Garrison, F. H. Introduction to the History of Medicine, Philadelphia 1929, pp. 737, 919.

6 Wagner von Jauregg, J. Über die Einwirkung fieberhafter Erkrankungen auf Psychosen. Jahrb. Psychiatrie 1887, 7: 94-134.

7 Théodorides, J. Histoire de la Rage. Paris 1986, p. 207.

8 ib. p. 185.

9 Franklin, A. La vie privé d'autrefois. Les Médicaments. Paris 1891, p. 118.

10 Théodorides, l.c. p. 176.

11 Cabanès, D. Remèdes d'autrefois. Paris 1910, pp.409-33.

12 ib. pp. 388-408.

13 Ackerknecht, E. H., 1970, p. 69.

14 ib. p. 82.

15 Ackerknecht, E.H., Medicine at the Paris Hospital 1794-1848, Baltimore 1967, p. 62.

16 Haas, H., Spiegel der Arznei, Berlin 1956, p. 51, 225.

17 Ackerknecht, E. H., Suchtprobleme im Lauf der Jahrhunderte. Praxis 60: 1006-1008. Schadewaldt H., Zur Geschichte einiger Rauschdrogen. Mat. Med. Nordmark 24, 1972.

18 in W. Steinbrecher and H. Solms, Sucht und Mißbrauch, IV 62, Stuttgart 1975.

19 Ackerknecht 1970, p. 160.

20 ib. p. 197. Le Phénomène de la mode. Lausanne 1985, contains contributions on fashions in jurisdiction, technology, dresses, religion, insurance, research and medicine.

\section{Zusammenfassung}

In der Therapie wird leider nicht selten eine schlechte Methode durch eine ebenso schlechte ersetzt. Der Autor bringt eine Anzahl historischer Beispiele, wie den Wechsel von antipyretischer zu pyretischer Behandlung in den 1920er Jahren oder aus der Rabies-, Syphilis-, Fieber-, Krebs- und Sucht-Therapie vergangener Jahrhunderte, welche die Existenz von Moden auch in der Medizin zeigen.

Prof. Dr. med. Dr.h.c. mult.

Erwin H. Ackerknecht

Ottikerstraße 42

CH-8006 Zürich 